\title{
Role of Mu- and Delta-Opioid Receptors in the Nucleus Accumbens in Cocaine-Seeking Behavior
}

\author{
Diana Simmons' and David W Self*, \\ 'Department of Psychiatry and the Neuroscience Graduate Program, The Seay Center for Basic and Applied Research in Psychiatric Illness, UT \\ Southwestern Medical Center, Dallas, Texas, USA
}

\begin{abstract}
Earlier studies suggest that opioid receptors in the ventral tegmental area, but not the nucleus accumbens (NAc), play a role in relapse to drug-seeking behavior. However, environmental stimuli that elicit relapse also release the endogenous opioid $\beta$-endorphin in the NAc. Using a within-session extinction/reinstatement paradigm in rats that self-administer cocaine, we found that NAc infusions of the muopioid receptor (MOR) agonist DAMGO moderately reinstated responding on the cocaine-paired lever at low doses ( $1.0-3.0 \mathrm{ng} / \mathrm{side}$ ), whereas the delta-opioid receptor (DOR) agonist DPDPE induced greater responding at higher doses (300-3000 ng/side) that also enhanced inactive lever responding. Using doses of either agonist that induced responding on only the cocaine-paired lever, we found that DAMGO-induced responding was blocked selectively by pretreatment with the MOR antagonist, CTAP, whereas DPDPE-induced responding was selectively blocked by the DOR antagonist, naltrindole. Cocaine-primed reinstatement was blocked by intra-NAc CTAP but not naltrindole, indicating a role for endogenous MOR-acting peptides in cocaine-induced reinstatement of cocaine-seeking behavior. In this regard, intra-NAc infusions of $\beta$-endorphin (I00-1000 ng/side) induced marked cocaine-seeking behavior, an effect blocked by intra-NAc pretreatment with the MOR but not DOR antagonist. Conversely, cocaine seeking elicited by the enkephalinase inhibitor thiorphan ( $1-10 \mu \mathrm{g} / \mathrm{side}$ ) was blocked by naltrindole but not CTAP. MOR stimulation in more dorsal caudate-putamen sites was ineffective, whereas DPDPE infusions induced cocaine seeking. Together, these findings establish distinct roles for MOR and DOR in cocaine relapse and suggest that NAc MOR could be an important therapeutic target to neutralize the effects of endogenous $\beta$ endorphin release on cocaine relapse.
\end{abstract}

Neuropsychopharmacology (2009) 34, 1946-1957; doi:I0.1038/npp.2009.28; published online II March 2009

Keywords: reinstatement; $\beta$-endorphin; thiorphan; DAMGO; DPDPE; relapse

\section{INTRODUCTION}

Drug addiction involves dysregulation in brain reward circuitry leading to compulsive drug use (Dackis and O'Brien, 2001; Kalivas and Volkow, 2005; Koob and Le Moal, 2001). In addition to drug reward, the mesolimbic dopamine system plays an integral role in relapse to drugseeking behavior, as stimuli that elicit drug seeking also activate dopamine neurons in the ventral tegmental area (VTA) leading to dopamine release in forebrain regions, such as the nucleus accumbens (NAc) (Phillips et al, 2003; Pruessner et al, 2004; Self and Nestler, 1998; Shalev et al, 2002; Spealman et al, 1999; Stewart, 2000). Opioid receptors also play a role in relapse to cocaine seeking in animal models, as systemic treatment with naltrexone inhibits

*Correspondence: Dr DW Self, Department of Psychiatry, University of Southwestern Medical Center, 5323 Harry Hines Blvd., Dallas, TX 75390-9070, USA, Tel: + 214648 1237, Fax: + 2146484947 ,

E-mail: david.self@utsouthwestern.edu

Received 8 November 2008; revised 28 January 2009; accepted 5 February 2009 cocaine seeking elicited by exposure to cocaine-associated cues (Burattini et al, 2008). Similarly, cocaine-primed cocaine seeking is blocked by systemic administration of the partial mu-opioid receptor (MOR) agonist buprenorphine, the delta-opioid receptor (DOR) antagonist naltrindole, or the nonspecific opioid antagonist naltrexone (Comer et al, 1993; Gerrits et al, 2005).

Stewart (1984) and colleagues found that opioid receptors in the VTA play a role in reinstatement of cocaine and heroin seeking, as intra-VTA morphine treatments trigger drug seeking in an extinction/reinstatement paradigm, an animal model of relapse. This effect is thought to involve local disinhibition of dopamine neurons in the VTA, leading to dopamine release in the NAc (Ford et al, 2006; Johnson and North, 1992; Leone et al, 1991). In contrast, earlier studies suggest that opioid receptors localized in the NAc do not play a role in drug seeking, as intra-NAc morphine treatments fail to reinstate cocaine or heroin seeking (Stewart and Vezina, 1988; Tang et al, 2005), and blockade of NAc MOR with the selective MOR antagonist CTAP (D-Phe-Cys-Tyr-D-Trp-Arg-Thr-Pen-Thr- $\mathrm{NH}_{2}$ ) failed to significantly alter cocaine-primed reinstatement of 
cocaine seeking (Tang et al, 2005). However, endogenous opioid peptides, such as $\beta$-endorphin, are released in the NAc by cocaine, and stressful situations (Roth-Deri et al, 2004, 2003; Zangen and Shalev, 2003), events that trigger the reinstatement of cocaine seeking, and intra-NAc morphine infusions induce a conditioned place preference (van der Kooy et al, 1982).

Opioid receptors are highly expressed by NAc neurons (Mansour et al, 1995, 1987), and local opioid infusions in the NAc modulate behavior in a biphasic manner. Thus, microgram doses of (D-Ala ${ }^{2}, \mathrm{~N}-\mathrm{Me}-\mathrm{Phe}^{4}$, glycinol $\left.^{5}\right)$-enkephalin (DAMGO) (MOR agonist) or morphine infused in the NAc initially suppress locomotion but subsequently induce hyper locomotion (Cunningham and Kelley, 1992; Meyer et al, 1994). Lower doses of DAMGO decrease the latency for hyper locomotion to occur (Meyer et al, 1994). As doses of agonists used in these locomotor studies are similar to those used in prior reinstatement studies, it is possible that the behavioral suppressive effects masked the potential of NAc opioid receptor stimulation to trigger the reinstatement of drug-seeking behavior. Moreover, NAc infusions of opioid agonists induce feeding behavior but also with a prolonged latency to initiate feeding (Bakshi and Kelley, 1993; Kelley et al, 2005). Similarly, intra-NAc infusions of DAMGO increase the motivation for food on a progressive ratio reinforcement schedule, and where response breakpoints are obtained after some delay (Zhang et al, 2003). Therefore, it is possible that these delayed motivational effects reflect the initial suppressive effects of high-dose MOR agonist infusions.

In this study, we investigated the role of NAc opioid receptors in the reinstatement of cocaine-seeking behavior using MOR- and DOR-selective ligands and endogenous opioid peptides. We found that NAc infusions of MOR and DOR agonists effectively reinstate cocaine seeking through selective actions at their respective receptors. Stimulation of NAc opioid receptors by the endogenous peptides, $\beta$-endorphin and enkephalins, also induced cocaine-seeking behavior. The results clearly establish that either MOR or DOR stimulation in the NAc is sufficient to elicit cocaine-seeking behavior, and that MOR receptors play an important role in cocaine-primed relapse. These findings also suggest that persistent neuroadaptations in NAc opioid receptors following chronic cocaine use could contribute to drug-seeking behavior in prolonged abstinence.

\section{MATERIALS AND METHODS}

\section{Animals and Housing Conditions}

Male Sprague-Daley rats weighing 225-275 g (Charles River Laboratories, Kingston, NY) were individually housed in wire cages with food and water available ad libitum, except during lever press training. Experiments were conducted during the light cycle of a $12: 12 \mathrm{~h}$ light/dark cycle (lights on at 0700 hours) in accordance with guidelines established by the National Institute of Health and the Institutional Animal Care and Use Committee at the University of Texas Southwestern Medical Center.

\section{Sucrose Lever Press Training and Surgery}

Lever-press training, self-administration, and reinstatement testing were performed in operant test chambers (MedAssociates, East Fairfield, VT). Chambers were equipped with two response levers and an infusion pump as described earlier (Edwards et al, 2007). Animals were food-restricted to prevent weight gain and trained to lever-press for sucrose pellets on a fixed ratio 1 (FR1) reinforcement schedule until an acquisition criteria of 100 sucrose pellets consumed for 3 consecutive test days was reached. Following lever-press training, animals were fed ad libitum for at least 1 day before surgery. Animals were anesthetized and implanted with a chronic indwelling catheter into the jugular vein that exited subcutaneously on the back. An intracranial, 26guage bilateral guide cannula was aimed at the NAc ( $\pm 1.5 \mathrm{~mm}$ lateral; $1.7 \mathrm{~mm}$ anterior to bregma; -5.7 ventral to dura with the level skull) or caudate putamen $(\mathrm{CPu})$ ( $\pm 1.5 \mathrm{~mm}$ lateral; $1.7 \mathrm{~mm}$ anterior to bregma; $-3.2 \mathrm{~mm}$ ventral to dura) (Paxinos and Watson, 1998). Dummy and infusion cannulae (33 gauge) were cut to extend $1 \mathrm{~mm}$ beyond the guide cannulae tip, and dummy cannulae remained in place until the day of intracranial drug infusion. Animals were allowed 5-7 days to recover before starting the experiment.

\section{Cocaine Self-Administration and Within-Session Reinstatement Testing}

Animals were tested in a within-session extinction/reinstatement paradigm as described earlier (Bachtell et al, 2005). Briefly, animals self-administered cocaine $(0.5 \mathrm{mg} / \mathrm{kg}$ in $0.1 \mathrm{ml}$ over $5 \mathrm{~s}$, time-out period $15 \mathrm{~s}$ ) in daily $4 \mathrm{~h}$ sessions for 5-6 days/week until a criteria of 3 consecutive days of $<10 \%$ variance in mean cocaine intake was reached $(\sim 3$ weeks). During the $5 \mathrm{~s}$ injection, a cue light above the lever was illuminated, whereas the house light was turned off for the entire injection and time-out period. Subsequently, animals were trained in the within-session extinction paradigm that consisted of $1 \mathrm{~h}$ cocaine availability followed by $3 \mathrm{~h}$ extinction conditions in which only responsecontingent injection cues were available. Animals extinguished responding to criteria of $\leqslant 5$ responses at either the drug-paired or the inactive lever for the final hour of the session for at least three consecutive sessions, while maintaining a minimum of 15 self-administered cocaine injections with $\pm 10 \%$ variability in the first hour of the session. Mean cocaine self-administration on the test day was $25 \pm 0.74(\mathrm{NAc})$ and $26 \pm 0.95(\mathrm{CPu})$ injections/h. Test days were conducted with an intra-NAc infusion of MOR and DOR agonists alone $(0.5 \mu \mathrm{l} / \mathrm{side}$ over $2 \mathrm{~min})$ or in combination as sequential antagonist/agonist infusions ( $1.0 \mu \mathrm{l} /$ side total volume) immediately before the final hour of the test session. For cocaine priming experiments, animals received $\mathrm{NAc}$ or $\mathrm{CPu}$ antagonist infusions followed immediately by iv priming with saline $(0.4 \mathrm{ml})$ or cocaine $(2.0 \mathrm{mg} / \mathrm{kg}$ in $0.4 \mathrm{ml})$. Following each test day, animals returned to within-session extinction training until stable self-administration and extinction criteria were reached for at least two consecutive sessions before the next test. Animals received a maximum of eight intracranial test infusions. 


\section{Locomotor Testing}

Some animals trained in the within-session reinstatement paradigm were given 1 week off from cocaine selfadministration and tested for locomotor responses to agonist infusions in the $\mathrm{NAc}$ or $\mathrm{CPu}$ using peak doses for reinstatement that were selective for the drug-paired lever. The locomotor testing apparatus consisted of a circularshaped plexiglass arena with $12 \mathrm{~cm}$ wide metal floors (MedAssociates) with four pairs of photocells located at $90^{\circ}$ intervals around the $1.95 \mathrm{~m}$ perimeter to record locomotor activity. Animals were habituated for $2 \mathrm{~h}$ in the dark followed by an intra-NAc or intra-CPu drug infusion and returned to the locomotor chambers for $2 \mathrm{~h}$ of subsequent testing. Testing of each drug was randomized and performed on consecutive days. Animals received five injections in locomotor tests.

\section{Histological Confirmation of Injection Sites}

Animals were anesthetized with chloral hydrate, and cresyl violet $(0.3 \mu \mathrm{l})$ was infused into the NAc or $\mathrm{CPu}$ through the guide cannula. Animals were immediately decapitated and brains removed. Slices $(0.8 \mathrm{~mm}$ thick $)$ were collected throughout the forebrain and analyzed under a dissecting microscope for the location of the infusion sites according to the coordinates of Paxinos and Watson (1998).

\section{Drugs}

Drugs used were DAMGO, DPDPE ((D-Pen $\left.{ }^{2}, \mathrm{D}-\mathrm{Pen}^{5}\right)$ enkephalin), CTAP, $\beta$-endorphin, met-enkephalin, and thiorphan (Bachem Bioscience Inc., King of Prussia, PA), and naloxone and naltrindole (Sigma-Aldrich, Atlanta, GA). Ligands were dissolved in $0.9 \%$ sterile saline except thiorphan, which was dissolved in 1:4 DMSO/saline. Cocaine hydrochloride was obtained from the National Institute on Drug Abuse (Research Triangle Park) and dissolved in $0.9 \%$ sterile saline.

\section{Statistical Analysis}

As not all animals completed an experiment, data were analyzed using a two-factor mixed regression analysis (SAS 9.1.3) of treatment $\times$ lever, followed by main effects analysis of each lever separately. Post hoc tests utilized one- or twotailed Dunnett's tests where appropriate for comparison with controls and Tukey's honestly significant difference test for pair-wise comparison where appropriate. Locomotor data were analyzed by one-way repeated measures ANOVA on treatment for each hour tested. Post hoc tests utilized Dunnett's one-tailed test for comparison with controls.

\section{RESULTS}

\section{MOR and DOR Involvement in Reinstatement}

We first determined whether NAc infusions of the MORselective agonist, DAMGO, and the DOR-selective agonist, DPDPE, could reinstate non-reinforced drug-paired lever responding following extinction of cocaine seeking. Intra-
NAc infusions of DAMGO produced an inverted U-shaped dose-response curve (Figure 1a) for non-reinforced responding on the drug-paired but not inactive lever (dose $\times$ lever: $\mathrm{F}_{6,161}=2.37, p=0.032$ ), with a main effect of both dose $\left(\mathrm{F}_{6,161}=3.52, p=0.003\right)$ and lever $\left(\mathrm{F}_{1,161}=46.01\right.$, $p<0.001)$. DAMGO induced moderate peak rates of responding at very low doses (1-3 ng/side) when compared with vehicle infusions without increasing inactive lever responding, whereas higher doses $(10 \mathrm{ng} / \mathrm{side})$ led to reduced responding (drug-paired lever: $\mathrm{F}_{6,66}=3.33, p=0.006$; inactive lever: $\left.\mathrm{F}_{6,66}=1.13, p=\mathrm{NS}\right)$. Similarly, intra-NAc infusions of DPDPE produced an inverted U-shaped dose-response curve (Figure $1 \mathrm{~b}$ ), but induced greater responding at higher doses of $300-3000 \mathrm{ng} /$ side (dose: $\mathrm{F}_{6,113}=12.09, p<0.001$; lever: $\left.\mathrm{F}_{1,113}=28.16, p<0.001\right)$. Unlike DAMGO, DPDPE induced substantial and significant lever pressing of both drug-paired and inactive levers compared with vehicle (drug-paired lever: $\mathrm{F}_{6,40}=11.37, p<0.001$; inactive lever: $\mathrm{F}_{6,40}=3.34, p=0.009$ ). Inactive lever responding increased significantly only at the peak dose for drug-paired lever responding (1000 ng/side).

\section{Antagonist Inhibition of Agonist-Mediated Reinstatement}

To determine whether DAMGO-stimulated reinstatement of cocaine seeking was mediated by MOR stimulation in the
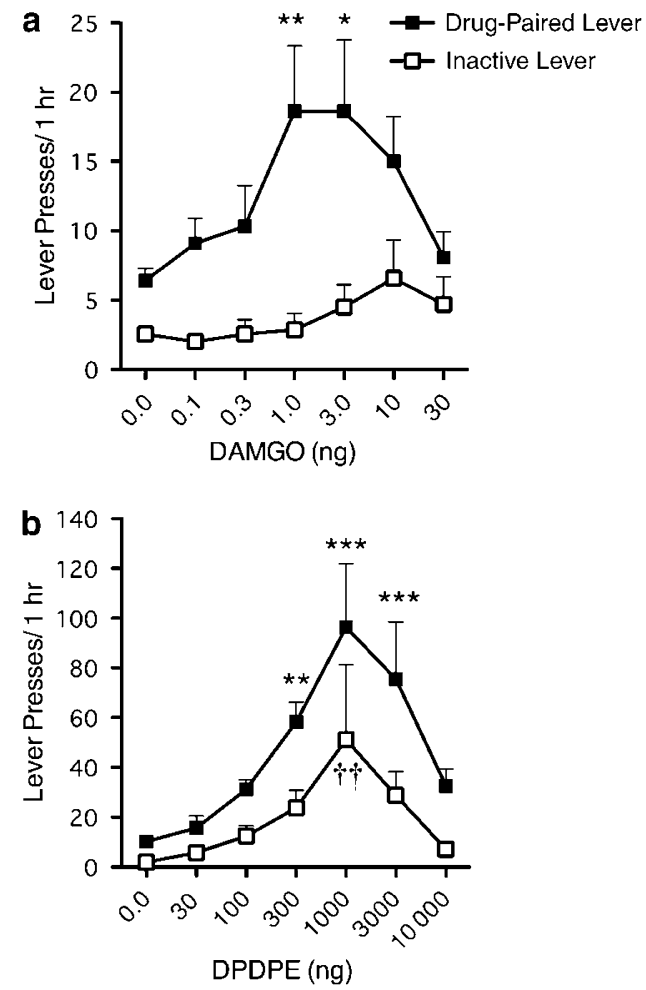

Figure I Intra-NAc infusions of (a) the mu-opioid receptor-selective agonist DAMGO or (b) the delta-opioid receptor-selective agonist DPDPE increase non-reinforced drug-paired lever responding in a within-session reinstatement procedure. Data represent the mean \pm SEM for doses of DAMGO ( $n=9-27$ animals/treatment) and DPDPE $(n=5-22$ animals/ treatment). Symbols indicate that drug-paired lever $(* p<0.05$, $* * * 0.01$ **** $p<0.00$ I) or inactive lever $\left({ }^{\dagger \dagger} p<0.01\right)$ differs from vehicle-infused controls by Dunnett's post hoc tests. 
NAc, we tested the ability of the MOR-selective antagonist, CTAP, to block DAMGO-primed reinstatement using the lowest effective dose from the earlier experiment ( $1 \mathrm{ng} /$ side). Intra-NAc pretreatment of CTAP dose dependently blocked DAMGO-primed reinstatement (Figure 2a; dose $\times$ lever: $\left.\mathrm{F}_{6,172}=7.82, \quad p<0.001\right)$, with a main effect of dose $\left(\mathrm{F}_{6,172}=7.78, \quad p<0.001\right)$ and lever $\quad\left(\mathrm{F}_{1,172}=123.36\right.$, $p<0.001)$. Non-reinforced responding at the drug-paired lever was blocked with maximally effective doses as low as $0.1 \mathrm{ng} /$ side of CTAP (drug-paired lever: $\mathrm{F}_{6,67}=8.59$, $p<0.001$; inactive lever: $\mathrm{F}_{6,67}=1.19, p=\mathrm{NS}$ ). Similarly, we tested the DOR-selective antagonist, naltrindole, against the lowest effective dose for DPDPE-induced reinstatement that did not increase inactive lever responding $(300 \mathrm{ng})$. Figure $2 \mathrm{~b}$ shows that intra-NAc treatment of naltrindole reduced DPDPE-primed reinstatement in a dose-dependent manner, achieving control levels at $1000 \mathrm{ng} /$ side (dose $\times$ lever: $\mathrm{F}_{4,139}=2.85, p=0.026$; dose: $\mathrm{F}_{4,139}=11.35, p<0.001$; lever: $\left.\mathrm{F}_{1,139}=55.54, p<0.001\right)$. Drug-paired lever responding was significantly attenuated starting at $300 \mathrm{ng} / \mathrm{side}$, with the maximal suppression at $1000 \mathrm{ng} / \mathrm{side}\left(\mathrm{F}_{4,58}=11.63\right.$, $p<0.001)$. Naltrindole produced some mild suppression of responding on the inactive lever (inactive lever: $\mathrm{F}_{4,58}=2.48$, $p=0.05)$.

\section{a DAMGO Reinstatement}
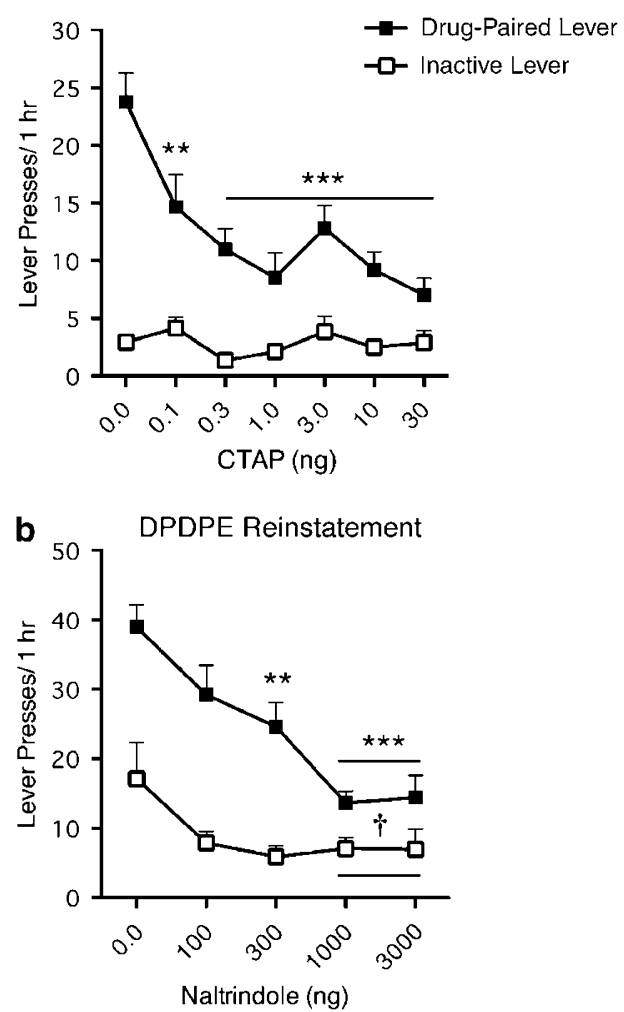

Figure 2 Intra-NAc pretreatment with (a) the mu-opioid receptorselective antagonist CTAP followed by I ng DAMGO and (b) the deltaopioid receptor-selective antagonist naltrindol followed by $300 \mathrm{ng}$ DPDPE dose dependently attenuates reinstatement of cocaine seeking. Data represent the mean \pm SEM for DAMGO/CTAP $(n=13-22$ animals/ treatment) and DPDPE/naltrindole $(n=18-20$ animals/treatment) combinations. Symbols indicate that drug-paired lever $(* * p<0.01$, ***** $p \leqslant 0.00 \mathrm{I}$ ) or inactive lever ( $\left.{ }^{\dagger} p<0.05\right)$ differs from agonist/vehicle-infused controls by Dunnett's post hoc tests.
Drug Specificity and Antagonist Inhibition of CocaineMediated Reinstatement

To determine whether DAMGO- and DPDPE-induced cocaine seeking was specific to MOR or DOR blockade, MOR and DOR agonists and antagonists were tested in a cross-blockade experimental design. Animals were given intra-NAc infusions of DAMGO (1 ng/side) or DPDPE $(300 \mathrm{ng} / \mathrm{side})$ following pretreatment with maximally effective doses of CTAP ( $30 \mathrm{ng} / \mathrm{side})$, naltrindole $(1000 \mathrm{ng} /$ side), or vehicle. Figure 3a shows that DAMGO-induced reinstatement of drug-paired lever responding was selectively blocked by CTAP, but not naltrindole, when compared with vehicle (treatment $\times$ lever: $F_{2,82}=5.09$, $p=0.008$; treatment: $\mathrm{F}_{2,82}=4.84, \quad p=0.01$; lever: $\left.\mathrm{F}_{1,82}=68.65, \quad p<0.001\right)$. CTAP significantly attenuated drug-paired lever responding $\left(\mathrm{F}_{2,29}=5.61, p=0.009\right)$, with no effect on inactive lever responding $\left(\mathrm{F}_{2,29}=0.40\right.$, $p=$ NS). Conversely, Figure $3 \mathrm{~b}$ shows that DPDPE-induced reinstatement was selectively blocked by naltrindole but not CTAP (treatment: $F_{2,40}=8.83, p<0.001$; lever: $\left.\mathrm{F}_{1,40}=39.01, p<0.001\right)$, with attenuation mainly on the drug-paired lever $\left(\mathrm{F}_{2,13}=5.65, p=0.017\right)$ and a trend for reduction in lower responding on the inactive lever $\left(\mathrm{F}_{2,13}=2.87, p=0.092\right)$. Together, these results indicate that a selective stimulation of either MOR or DOR in the NAc is sufficient to independently trigger cocaine-seeking behavior.

Given that cocaine injections are known to increase endogenous opioid release in the NAc, we tested whether MOR or DOR in the NAc plays a role in cocaine-primed reinstatement of cocaine-seeking behavior. Animals were given NAc pretreatments with vehicle, CTAP, or naltrindole immediately before an iv cocaine injection $(2 \mathrm{mg} / \mathrm{kg})$ in the reinstatement paradigm. As the peak dose of CTAP (30 ng against $1 \mathrm{ng}$ DAMGO) had no effect on cocaine-primed reinstatement (data not shown), we tested a higher dose of CTAP ( $3 \mu \mathrm{g} / \mathrm{side})$ more commonly used in intracranial studies (Soderman and Unterwald, 2008; Tang et al, 2005), along with the $1 \mu \mathrm{g} / \mathrm{side}$ dose of naltrindole. The affinity of CTAP for MOR $(2.36 \pm 0.46 \mathrm{nM})$ is 15.7 times lower than that of naltrindole for DOR $(0.15 \pm 0.01 \mathrm{nM})$ (Bonner et al, 2000; Clayson et al, 2001; Pelton et al, 1986; Portoghese et al, 1988), indicating that relatively higher amounts of CTAP than naltrindole may be required to inhibit endogenous opioid activity at MOR than DOR. Furthermore, the doses of CTAP and naltrindole used were roughly molar equivalents (5.4 and $4.8 \mu \mathrm{M}$, respectively). Intra-NAc pretreatment with CTAP significantly reduced cocaine-primed reinstatement compared with vehicle pretreatment (Figure 3c), whereas pretreatment with naltrindole did not (treatment $\times$ lever: $\mathrm{F}_{2,82}=4.17, \quad p=0.019 ; \quad$ treatment: $\mathrm{F}_{2,82}=5.12$, $p=0.008$; lever: $\left.\mathrm{F}_{1,82}=62.51, p=0.001\right)$. CTAP significantly attenuated drug-paired lever responding in response to an iv cocaine prime without affecting inactive lever responding (drug-paired lever: $\mathrm{F}_{2,17}=7.08, p=0.006$; inactive lever: $\mathrm{F}_{2,17}=0.38, \quad p=\mathrm{NS}$ ). These findings indicate that endogenous opioid release in the NAc contributes to cocaine-primed reinstatement of cocaine seeking through the activation of MOR but not DOR. 


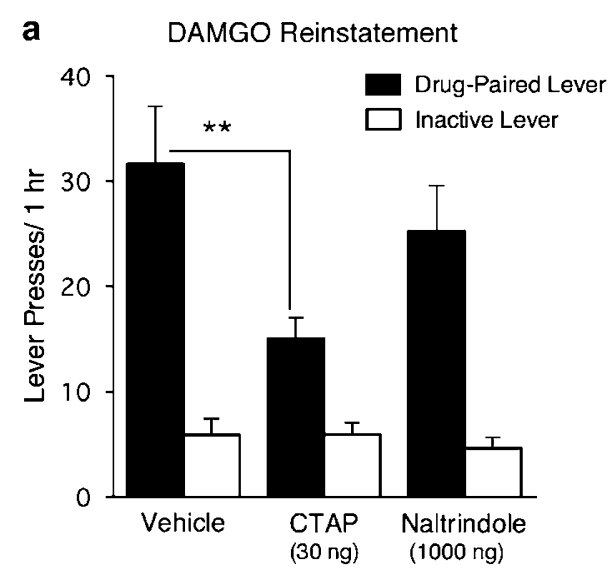

intra-NAc infusions of $\beta$-endorphin and met-enkephalin. Intra-NAc infusions of $\beta$-endorphin dose dependently reinstated responding on the cocaine-paired lever, with effective doses ranging from 100 to $1000 \mathrm{ng} /$ side (Figure 4a; dose $\times$ lever: $\mathrm{F}_{4,103}=4.07, p=0.004 ;$ dose: $\mathrm{F}_{4,103}=12.11$, $p<0.001$; lever: $\left.F_{1,103}=51.27, \quad p<0.001\right) . \quad \beta$-Endorphin infusions significantly increased drug-paired lever responding $\left(\mathrm{F}_{4,42}=8.82, p<0.001\right)$, with a minor increase in inactive lever responding at the highest dose (inactive lever: $\left.\mathrm{F}_{4,42}=7.32, p<0.001\right)$. In contrast, intra-NAc infusions of met-enkephalin failed to reinstate cocaine seeking up to doses as high as $10 \mu \mathrm{g} /$ side (Figure $4 \mathrm{~b} ; \mathrm{F}_{5,102}=0.44, p=\mathrm{NS}$ ).
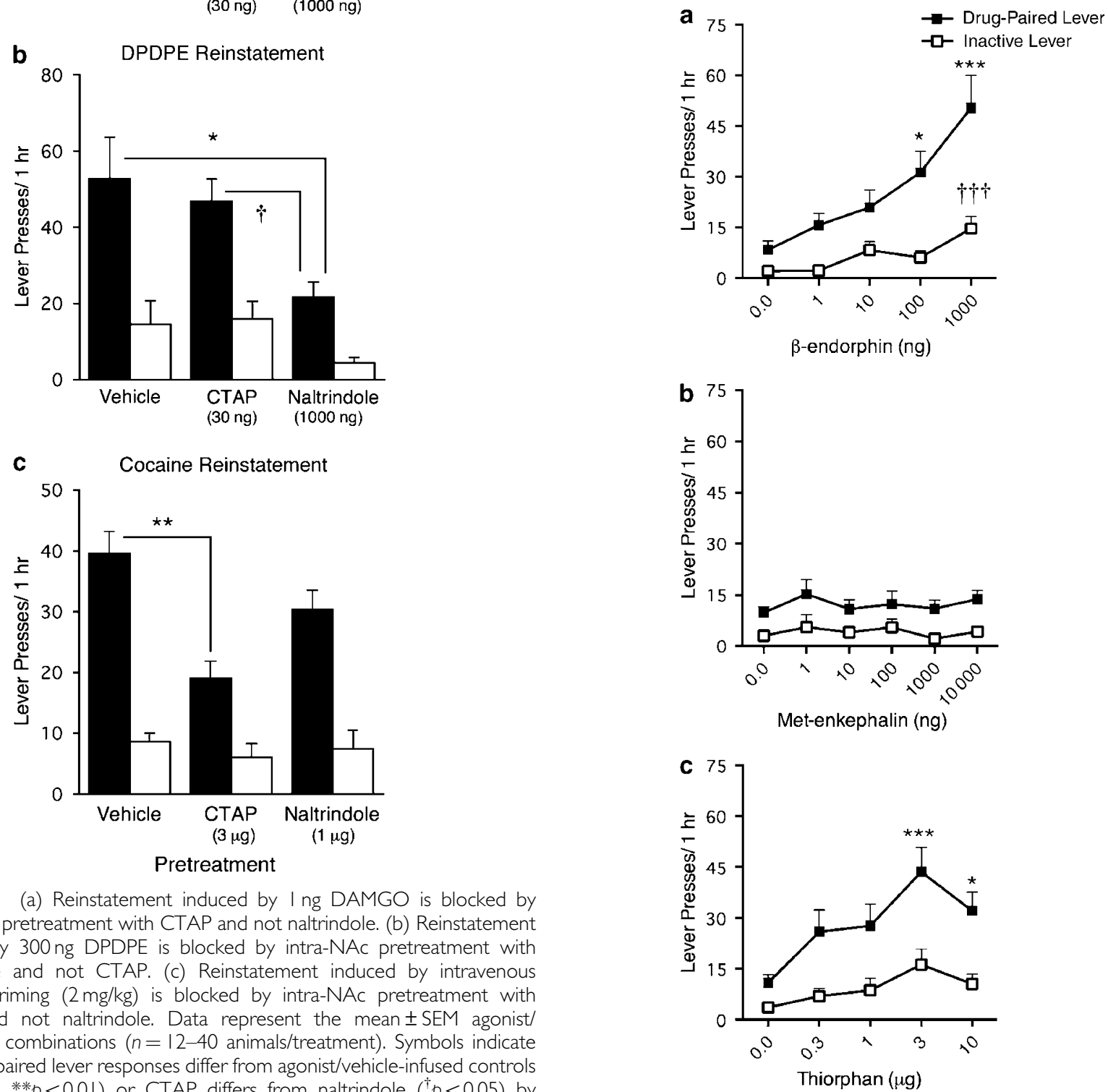

Figure 3 (a) Reinstatement induced by I ng DAMGO is blocked by intra-NAc pretreatment with CTAP and not naltrindole. (b) Reinstatement induced by $300 \mathrm{ng}$ DPDPE is blocked by intra-NAc pretreatment with naltrindole and not CTAP. (c) Reinstatement induced by intravenous cocaine priming $(2 \mathrm{mg} / \mathrm{kg})$ is blocked by intra-NAc pretreatment with CTAP and not naltrindole. Data represent the mean \pm SEM agonist/ antagonist combinations ( $n=12-40$ animals/treatment). Symbols indicate that drug-paired lever responses differ from agonist/vehicle-infused controls $\left(* p<0.05\right.$, ** $p<0.0$ I) or CTAP differs from naltrindole $\left({ }^{\dagger} p<0.05\right)$ by Tukey's HSD post hoc tests.

\section{Endogenous Opioid Peptides Reinstate Cocaine Seeking in the NAc}

The next set of experiments determined the ability of endogenous opioids to reinstate cocaine seeking using 
As earlier studies used enkephalin derivatives, suggesting that enkephalins are degraded too rapidly to produce effects in behavioral tests (Kalivas and Bronson, 1985; Phillips et al, 1983), we used the enkephalinase inhibitor thiorphan to determine if the accumulation of endogenously released enkephalins would reinstate cocaine seeking. Intra-NAc thiorphan infusions effectively reinstated responding to levels similar to $\beta$-endorphin (Figure $4 \mathrm{c}$; dose: $\mathrm{F}_{4,92}=6.77$, $p<0.001$; lever: $\left.\mathrm{F}_{1,92}=63.27, p<0.001\right)$. Thiorphan induced prominent responding on the drug-paired lever $\left(\mathrm{F}_{4,36}=4.55, p=0.004\right)$, with minor increases in responding on the inactive lever at the peak dose of $3.0 \mu \mathrm{g}$ that approached significance $\left(\mathrm{F}_{4,36}=2.48, p=0.061\right)$. These findings indicate that either MOR-preferring ( $\beta$-endorphin) or DOR-preferring (enkephalins) endogenous opioid peptides in the NAc are capable of eliciting cocaine-seeking behavior.

\section{Receptor Specificity of Endogenous Opioid-Induced Reinstatement of Cocaine Seeking}

Although $\beta$-endorphin and enkephalins preferentially interact with MOR and DOR respectively, they also interact with other opioid receptors. We tested the ability of $3 \mu \mathrm{g}$ CTAP, $1 \mu \mathrm{g}$ naltrindole, and the less-specific opioid antagonist naloxone to block $\beta$-endorphin- and thiorphan-induced reinstatement. Animals were given NAc infusions of maximal effective doses of $\beta$-endorphin $(1 \mu \mathrm{g} / \mathrm{side})$ or thiorphan $(3 \mu \mathrm{g} / \mathrm{side})$ immediately following vehicle, CTAP ( $3 \mu \mathrm{g} /$ side $)$, naltrindole $(1 \mu \mathrm{g} /$ side $)$, or naloxone $(10 \mu \mathrm{g} / \mathrm{side})$ pretreatments. Figure 5a shows that $\beta$-endorphin-induced reinstatement of cocaine seeking was selectively attenuated by CTAP or naloxone, but not naltrindole (treatment $x$ lever: $\mathrm{F}_{3,74}=4.83, \quad p=0.004$; treatment: $\mathrm{F}_{3,74}=10.45$, $p<0.001$; lever: $\left.\mathrm{F}_{1,74}=66.94, p<0.001\right)$, specifically reducing responding on the drug-paired lever $\left(\mathrm{F}_{3,27}=12.63\right.$, $p<0.001)$ and not on the inactive lever $\left(\mathrm{F}_{3,27}=0.94\right.$, $p=$ NS). Conversely, Figure $5 \mathrm{~b}$ shows that reinstatement elicited by the enkephalinase inhibitor thiorphan was blocked selectively by naltrindole or naloxone, but not significantly by CTAP (treatment: $\mathrm{F}_{3,69}=5.55, p=0.002$; lever: $\left.F_{1,69}=15.19, p<0.001\right)$. Naltrindole and naloxone reduced thiorphan-induced responding on the drug-paired and not inactive lever (drug-paired lever: $\mathrm{F}_{3,26}=4.45$, $p=0.012$; inactive lever: $\mathrm{F}_{3,26}=2.23, p=\mathrm{NS}$ ). Thus, the endogenous opioid peptide, $\beta$-endorphin, reinstates cocaine seeking through the selective activation of NAc MOR, whereas elevations in endogenous enkephalin levels trigger cocaine seeking primarily through DOR activation, consistent with their preference for these receptors.

\section{Regional Specificity For MOR- But Not DOR-Induced Reinstatement of Cocaine-Seeking Behavior}

To determine whether MOR and DOR stimulation of cocaine seeking was specific to the NAc, or due to potential spread up the cannulae shaft, we infused effective doses of all agonists $2.5 \mathrm{~mm}$ dorsal to the NAc site in the $\mathrm{CPu}$, a region shown to have similar expression patterns of opioid receptors as the NAc. Although none of the MOR-acting agonists or the enkephalinase inhibitor induced reinstatement in the $\mathrm{CPu}$ (Figure 6a), $\mathrm{CPu}$ infusions of DPDPE were
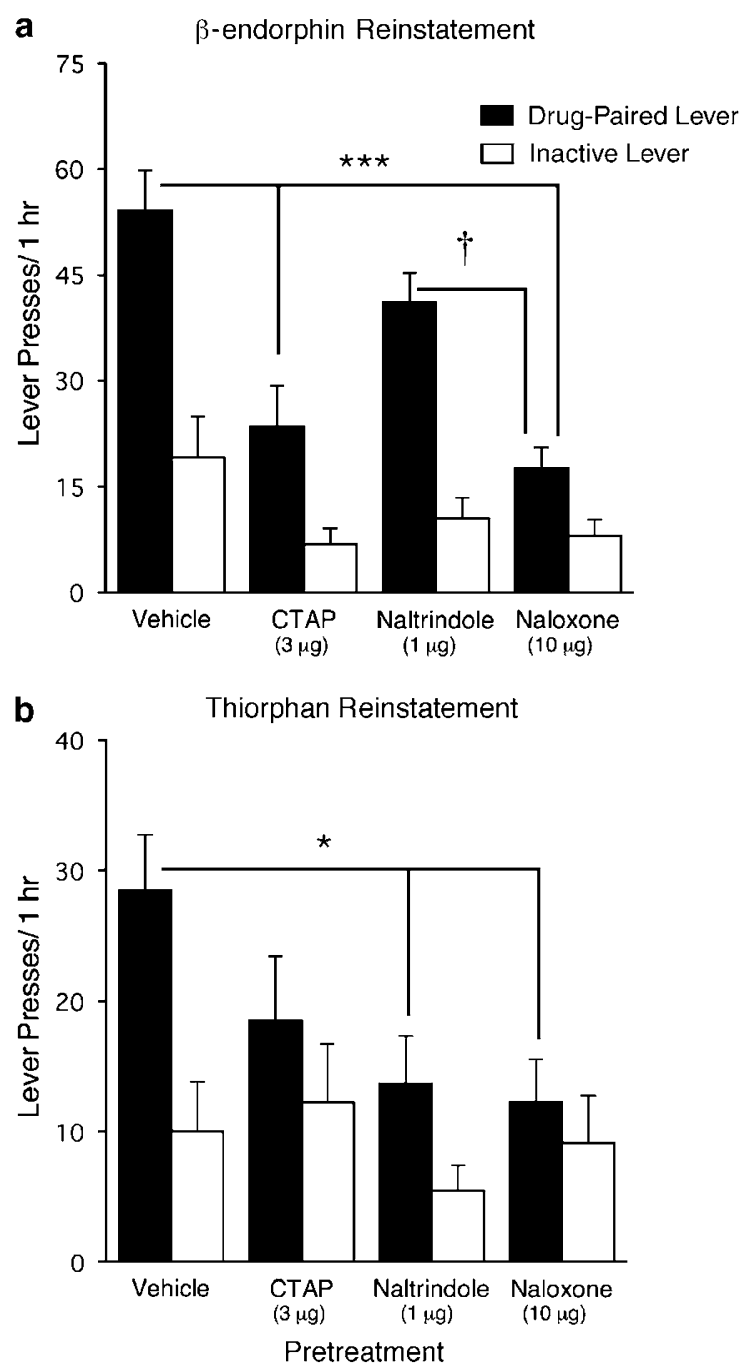

Figure 5 (a) Reinstatement induced by I $\mu \mathrm{g} \beta$-endorphin is blocked by intra-NAc pretreatment with CTAP or naloxone, but not naltrindole. (b) Reinstatement induced by $3 \mu \mathrm{g}$ thiorphan is blocked by intra-NAc pretreatment with naltrindole or naloxone, but not CTAP. Data represent the mean \pm SEM for $\beta$-endorphin/antagonist ( $n=9-17$ animals/treatment) and thiorphan/antagonist $(n=8-14$ animals/treatment) combinations. Symbols indicate that drug-paired lever responses differ from agonist/ vehicle-infused controls $(* p<0.05$, **** $p<0.00 \mathrm{I})$ or differs from naltrindole ( $\left.{ }^{\dagger} p<0.05\right)$ by Tukey's HSD post hoc tests.

sufficient to stimulate responding (treatment $\times$ lever: $\mathrm{F}_{4,97}=2.41, p=0.05$; treatment: $\mathrm{F}_{4,97}=6.51, p<0.001$; lever: $\left.\mathrm{F}_{1,97}=40.91, p<0.001\right)$, with increases in responding on both the drug-paired lever $\left(\mathrm{F}_{4,38}=4.61, p=0.004\right)$ and inactive lever $\left(\mathrm{F}_{4,38}=3.43, p=0.017\right)$. It should be noted, however, that the $300 \mathrm{ng} / \mathrm{side}$ dose of DPDPE elicited twice as much responding in the NAc than in the $\mathrm{CPu}$. In addition, intra- $\mathrm{CPu}$ pretreatment with $\mathrm{CTAP}$ at a dose that blocked cocaine-primed reinstatement in the NAc failed to alter cocaine seeking when infused into the $\mathrm{CPu}$ (Figure $6 \mathrm{~b}$ ) compared with vehicle-pretreated animals (treatment $\times$ lever: $\mathrm{F}_{1,14}=0.08, p=\mathrm{NS}$; treatment: $\mathrm{F}_{1,14}=0.09, p=\mathrm{NS}$; lever: $\left.F_{1,14}=10.21, p<0.01\right)$. Together, these data indicate that MOR involvement in reinstatement of cocaine seeking is specific to the NAc, whereas DORs in both sites are capable of triggering this behavior. 

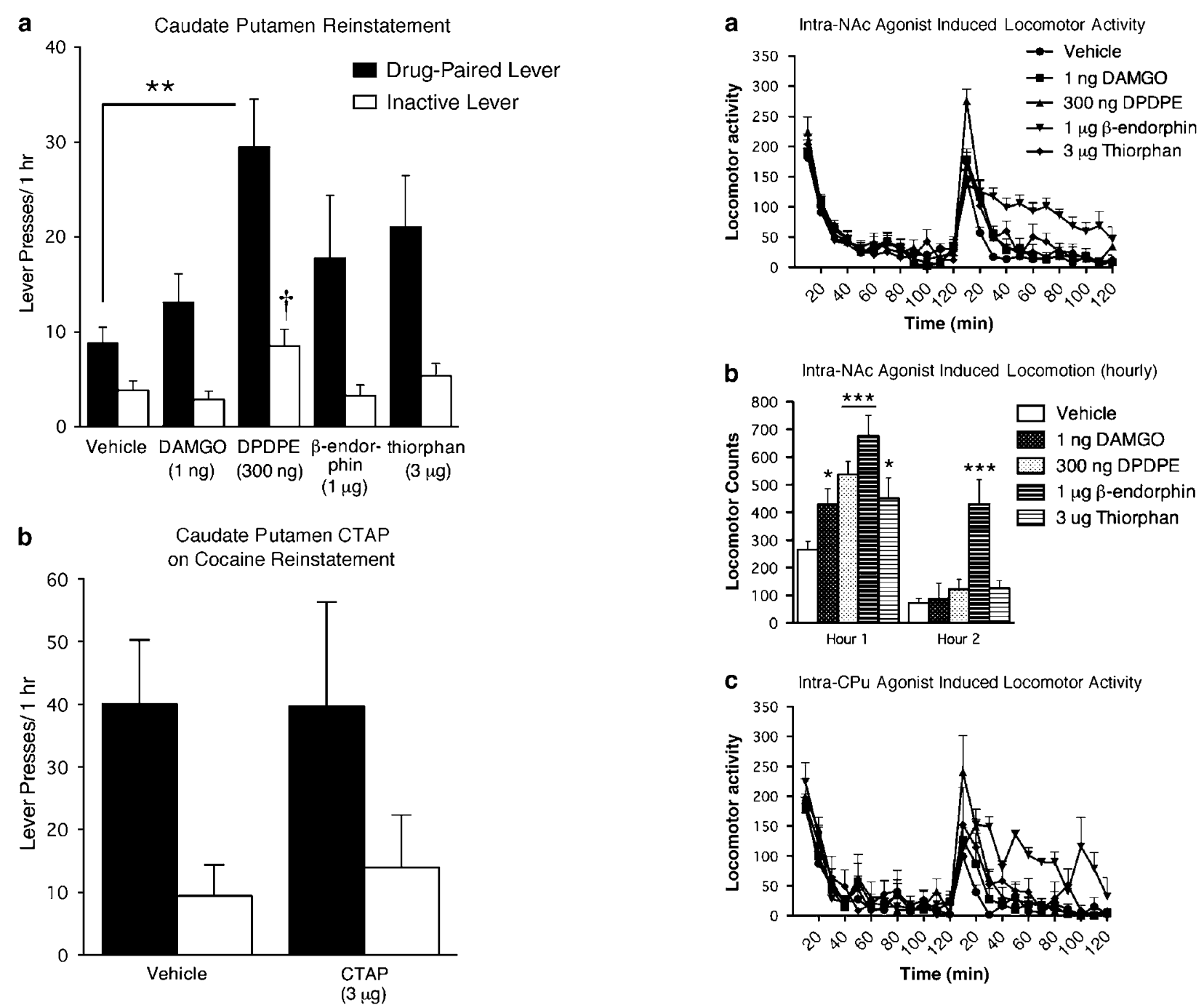

Figure 6 (a) Effective NAc doses of DAMGO, $\beta$-endorphin, and thiorphan are ineffective at reinstatement when infused in the $\mathrm{CPu}$, whereas intra-CPu DPDPE induces significant drug-paired and inactive lever responding. (b) Pretreatment with intra-CPu infusions of CTAP has no effect on reinstatement induced by intravenous cocaine priming $(2 \mathrm{mg} / \mathrm{kg})$. Data represent the mean \pm SEM for doses of agonists $(n=7-18$ animals/ treatment) and cocaine/antagonist ( $n=6-8$ animals/treatment) combinations. Symbols indicate that drug-paired lever responses $(* * p<0.01)$ or inactive lever responses ( $p<0.05$ ) differ from vehicle-infused controls by Dunnett's post hoc tests.

\section{Opioid Agonist Induction of Locomotor Behavior in Cocaine-Trained Animals}

Following 1-week withdrawal from cocaine self-administration and reinstatement testing, the locomotor response to intracranial infusions of DAMGO, DPDPE, $\beta$-endorphin and thiorphan was tested using doses that produced peak and primarily drug-paired lever responding when infused in the NAc. Figure $7 \mathrm{a}$ and $\mathrm{b}$ shows that all treatments increased locomotion for $1 \mathrm{~h}$ after infusion into the NAc when compared with vehicle infusions $\left(\mathrm{F}_{4,46}=8.429, p<0.001\right)$, whereas only $\beta$-endorphin increased locomotion for at least $2 \mathrm{~h}$ after infusion $\left(\mathrm{F}_{4,41}=8.258, p<0.001\right)$. Thus, the lower doses of DAMGO and DPDPE that triggered cocaine seeking

d Intra-CPu Agonist Induced Locomotion (hourly)

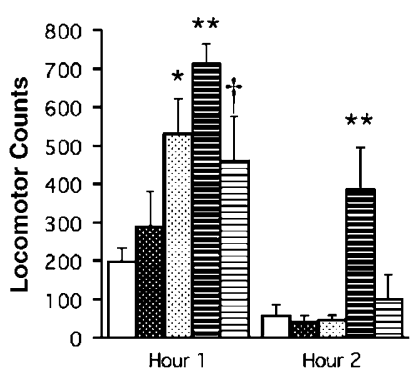

Figure 7 Effects of reinstating doses of agonist treatments on horizontal locomotion in cocaine-trained animals. (a) Timeline of locomotor behavior during habituation for $2 \mathrm{~h}$ and following intra-NAc infusion of opioid agonist. (b) All agonists increase locomotor behavior for I $\mathrm{h}$ when infused in the NAc whereas $\beta$-endorphin activity remains elevated during the second hour of testing. (c) Timeline of locomotor behavior in response to the intra-CPu infusion of opioid agonists. (d) Only DPDPE and $\beta$-endorphin increased locomotor responding in the $\mathrm{CPu}$, with a trend for thiorphan to increase locomotion. Data represent the mean \pm SEM for NAc $(n=7-13$ animals/treatment) and CPu ( $n=4-5$ animals/treatment). Symbols indicate (* $p<0.05$, *** $p<0.01$, **** $p<0.00$ I, $\left.{ }^{\dagger} p=0.059\right)$ lever differs from vehicleinfused controls by Dunnett's post hoc tests.

produced psychomotor effects without the delay typically observed with higher doses in earlier studies. Figure $7 \mathrm{c}$ and d shows that very similar locomotor responses were 
produced by infusions of DPDPE and $\beta$-endorphin in the $\mathrm{CPu}\left(\mathrm{F}_{4,16}=5.427, p=0.006\right)$, with a trend for thiorphan to increase locomotor activity during the first hour $(p=0.059)$. In contrast, intra-CPu infusions of DAMGO failed to significantly increase locomotion. Together, these findings suggest that although psychomotor activation may accompany reinstatement of cocaine seeking with NAc infusions, similar locomotor responses with $\mathrm{CPu}$ infusions are dissociated from cocaine seeking in many cases.

\section{Injection Sites}

Figure 8 illustrates the localization of all infusion sites in the $\mathrm{NAc}$ and $\mathrm{CPu}$ used in this study. Fourteen animals were eliminated from NAc studies, and three animals were eliminated from $\mathrm{CPu}$ studies, due to misplacement of one or both cannulae.

\section{DISCUSSION}

This study found that the selective stimulation of either MOR or DOR in the NAc is sufficient to reinstate cocaineseeking behavior in rats following extinction of cocaine selfadministration. Thus, NAc infusions of either the MORselective agonist, DAMGO, or the DOR-selective agonist, DPDPE, effectively elicited cocaine-seeking responses on the drug-paired lever that delivered cocaine injections during prior self-administration. The threshold dose for reinstating cocaine seeking was 300 times lower with DAMGO ( $1 \mathrm{ng} / \mathrm{side})$ than that with DPDPE $(300 \mathrm{ng} / \mathrm{side})$, whereas DPDPE induced greater peak rates of responding and was associated with generalized but lower rates of responding on the inactive lever. This latter effect with DPDPE could be related to psychomotor activation rather than motivation for cocaine, or an inability to appropriately discriminate the drug-paired from inactive levers with increased DOR stimulation, although a lower dose of DPDPE selectively induced responding on the drug-paired lever. Both of these metabolically stable opioid peptide agonists produced an inverted U-shaped dose-response curve, indicating that higher doses were ineffective, potentially explaining the failure to detect morphine-induced reinstatement of drug seeking at microgram doses used in earlier studies (Stewart and Vezina, 1988; Tang et al, 2005).

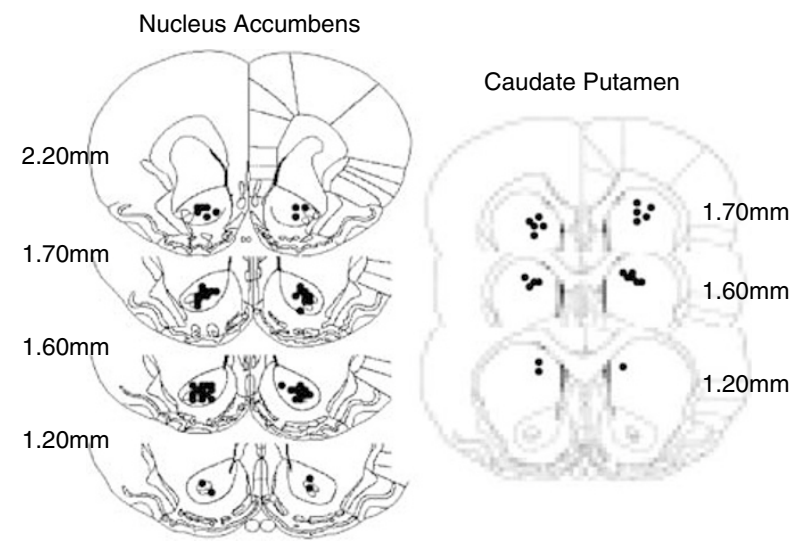

Figure 8 Localization of infusion sites in the medial NAc core and CPu ( +1.2 through $+2.2 \mathrm{~mm}$ from Bregma, Paxinos and Watson, 1998).
In contrast, intra-NAc infusions of the endogenous opioid peptide $\beta$-endorphin induced cocaine seeking with a monophasic dose-response curve up to $1 \mu \mathrm{g} /$ side, possibly reflecting the sensitivity of this peptide to metabolic degradation. Importantly, the reinstating effects of both DAMGO and $\beta$-endorphin were blocked by the MORselective antagonist CTAP, and not by the DOR-selective antagonist naltrindole. The ability of DAMGO and $\beta$ endorphin to reinstate cocaine seeking was localized to the NAc, as the failure of more dorsal $\mathrm{CPu}$ infusions to reinstate responding negates the possibility of diffusion along the cannulae shaft or into the cerebral ventricles. These data firmly establish that MORs in the NAc mediate relapse to cocaine-seeking behavior. Although the stimulation of MOR in dorsomedial $\mathrm{CPu}$ is ineffective, dorsolateral $\mathrm{CPu}$ sites could be involved in cocaine seeking, given that the inactivation of this site reduces cocaine-seeking behavior (See et al, 2007).

In addition, infusions of CTAP into the NAc, but not the $\mathrm{CPu}$, attenuated cocaine-primed reinstatement, possibly relating to the ability of cocaine to increase endogenous $\beta$-endorphin release in the NAc (Olive et al, 2001; Roth-Deri et al, 2003). Higher doses of CTAP $(3 \mu \mathrm{g})$ were required to attenuate cocaine-primed reinstatement than DAMGOprimed reinstatement (30 ng), possibly reflecting higher concentrations of cocaine-induced $\beta$-endorphin release relative to the very low doses of DAMGO that were effective (1-3 ng/side). The high dose of CTAP that attenuated cocaine-primed reinstatement also blocked $\beta$-endorphinprimed reinstatement that required a higher dose range $(0.1-1 \mu \mathrm{g})$ than found with DAMGO.

Cocaine-induced $\beta$-endorphin release in the NAc is blocked by dopamine receptor antagonist infusions in the arcuate nucleus of the hypothalamus (Doron et al, 2006), the primary source for $\beta$-endorphin innervation of the NAc. $\beta$-Endorphin release in the NAc also is induced by exposure to footshock stress, or the unmet expectation of cocaine reward under extinction conditions (Roth-Deri et al, 2003; Zangen and Shalev, 2003), situations that elicit cocaineseeking behavior. Thus, taken together with our findings, $\beta$-endorphin stimulation of MOR in the NAc could contribute to cocaine seeking elicited by cocaine priming, exposure to cocaine-associated environments, and stressful events. In contrast, an earlier study found that NAc pretreatment with CTAP does not block cocaine-primed reinstatement using longer acting intraperitoneal cocainepriming injections (Tang et al, 2005), whereas an effective blockade was found using shorter acting intravenous cocaine priming in our study. Another difference could involve the use of the within- $v s$ between-session extinction/ reinstatement paradigms.

Contrary to DAMGO and $\beta$-endorphin, cocaine seeking induced by DPDPE was blocked by pretreatment with DORbut not the MOR-selective antagonist in the NAc. NAc infusions of the enkephalinase inhibitor thiorphan (to elevate endogenous enkephalins) also reinstated cocaine seeking, and the effect was blocked by DOR antagonist pretreatment, although marginal (nonsignificant) attenuation was found with the MOR antagonist potentially relating to enkephalin activity at MOR. DOR stimulation in more dorsal $\mathrm{CPu}$ sites with DPDPE also induced a moderate degree of cocaine seeking, but with greater 
efficacy in the NAc. Moreover, the reinstating effect of DPDPE in the $\mathrm{CPu}$ was accompanied by a significant inactive lever responding, an effect not found with this DPDPE dose in the NAc, and potentially relating to psychomotor activation, as discussed above. In this regard, infusions of the enkephalinase inhibitor thiorphan in the $\mathrm{CPu}$ failed to reinstate cocaine seeking and had no effect on inactive lever responding in either striatal site. Together, the double dissociation with MOR- and DOR-selective ligands clearly indicates that MORs and DORs in the NAc mediate cocaine seeking through distinct and independent mechanisms.

Interestingly, blockade of DOR in the NAc failed to attenuate cocaine-primed reinstatement of cocaine seeking. Whether cocaine increases extracellular enkephalins in the NAc is unknown, but cocaine acutely increases preproenkephalin expression throughout the striatum (Hurd and Herkenham, 1992), although this acute effect is diminished with chronic cocaine administration (Arroyo et al, 2000; Mantsch et al, 2004). One study found that systemic administration of naltrindole decreases cocaine self-administration but only at doses that also suppressed locomotor behavior (de Vries et al, 1995). Another study showed reduced lever pressing for cocaine irrespective of reinforcement schedule (Reid et al, 1995), and intra-NAc infusions of an irreversible DOR-alkylating analog of naltrindole (Portoghese et al, 1990) decreased responding for cocaine on a more demanding progressive ratio schedule of reinforcement (Ward and Roberts, 2007), suggesting generalized effects on motor performance. In contrast, icv administration of the naltrindole analog strongly reduced heroin self-administration while only modestly decreasing cocaine self-administration on a less-demanding fixed-ratio reinforcement schedule (Martin et al, 2000), suggesting that endogenous DOR activity plays little role in the effects of cocaine. Similarly, our results are consistent with the notion that endogenous release of enkephalins in the NAc does not contribute to cocaine-primed reinstatement of cocaine seeking, but further tests are needed to determine whether cocaine seeking induced by stress or cocaine-associated cues involves endogenous enkephalinergic activity at NAc DOR.

Intra-NAc infusions of MOR and DOR agonists at doses that effectively reinstated cocaine seeking also increased horizontal locomotion, with $\beta$-endorphin infusions producing prolonged effects over $2 \mathrm{~h}$ of testing. Infusions of all treatments into the dorsomedial $\mathrm{CPu}$ also increased locomotion to similar levels, with the exception of the MOR agonist DAMGO, whereas only the DOR agonist DPDPE triggered cocaine seeking in this region. Although these data support the notion that DPDPE-induced reinstatement may be related to psychomotor activation, the dissociation of locomotor activity and cocaine seeking with infusions of $\beta$-endorphin and thiorphan in the $\mathrm{CPu}$ suggests that the reinstating effects of these treatments in the NAc are not related to generalized psychomotor activation. Moreover, although it could be argued that DAMGO-induced reinstatement is related to psychomotor activation, the lack of increases in inactive lever responding with DAMGO infusions suggests that reinstatement reflects motivational rather than motor effects. In contrast to reinstatement of cocaine seeking, NAc infusions of higher doses of DAMGO $(0.25-2.5 \mu \mathrm{g})$ induce a delayed increase in locomotion and preference for sucrose and high-fat foods often after a period of behavioral suppression (Cunningham and Kelley, 1992; Meyer et al, 1994; Zhang and Kelley, 1997; Kelley et al, 2005), whereas we found that very low doses induce locomotion and cocaine seeking without delay. These findings suggest that lower doses of DAMGO could be employed to elicit appetitive behavior without delay in future studies.

Although MOR and DOR are coupled to similar intracellular signaling pathways, their distinct involvement in modulating drug-seeking behavior can be attributed to differences in their subanatomical distribution. MORs are largely expressed extrasynaptically on dendrites and dendritic shafts of GABAergic and cholinergic cells within striatal patches (Svingos et al, 1997; Wang and Pickel, 1998) in which they modulate excitatory and GABAergic input to NAc neurons (Gracy et al, 1997). Presynaptic MOR can also modulate the release of GABA onto NAc neurons (Svingos et al, 1997). DOR can either directly or indirectly modulate dopamine release through expression on dopamine terminals or on GABAergic terminals apposed to dopamine terminals. DOR can also modulate postsynaptic responses in spiny neurons that receive dopamine input (Svingos et al, 1999). MOR colocalizes predominantly with preprotachykinin-positive neurons in patch compartments that constitute the direct striatal output, and more rarely with preproenkephalin-positive neurons of the striatal matrix that constitute the indirect output (Furuta et al, 2002). The differential expression patterns of MOR and DOR lend them different mechanisms of action, with DOR more frequently modulating inhibitory and dopaminergic input to the NAC and MOR primarily modulating NAc GABAergic neurons themselves (Svingos et al, 1999, 1997; Wang and Pickel, 1998).

Cocaine-primed reinstatement of cocaine seeking requires glutamatergic neurotransmission in the NAc core (Cornish and Kalivas, 2000; McFarland et al, 2003) and dopaminergic neurotransmission in the NAc shell (Anderson et al, 2003), although direct dopamine receptor stimulation in the medial NAc core elicits greater cocaine seeking than that in the shell or lateral core region (Bachtell et al, 2005, Schmidt et al, 2006). Although we did not compare core with shell subregions in this study, the ability of the MOR antagonist CTAP to block cocaine-primed cocaine seeking suggests that $\beta$-endorphin is released in the vicinity of the medial NAc. Given that the locomotoractivating effects of intra-NAc MOR- and DOR-selective agonists are not attenuated by dopamine depletion or chronic dopamine receptor blockade (Stinus et al, 1986; Churchill and Kalivas, 1992), it is likely that cocaine seeking elicited by MOR and DOR stimulation is mediated independent of dopamine release in the NAc. Furthermore, dopamine depletion leads to supersensitivity to MOR but not DOR agonist infusions in locomotor tests (Churchill and Kalivas, 1992).

Chronic cocaine administration modulates opioid receptor expression in the NAc (for review see Boutrel, 2008; Kreek, 2001), suggesting that changes in these receptors could alter the propensity for relapse during cocaine withdrawal. Free $\beta$-endorphin levels are decreased in the NAc and other brain regions within 1 day withdrawal from cocaine self-administration, potentially reflecting the 
depletion of endogenous stores (Sweep et al, 1989). Similarly, opioid receptor binding decreases immediately after and before the next scheduled cocaine self-administration session (Gerrits et al, 1999), possibly reflecting the release of endogenous opioids during cocaine self-administration. Chronic cocaine administered in a daily binge pattern transiently increases MOR but not DOR density and MOR-stimulated [35S]GTP $\gamma \mathrm{S}$ binding in the NAc (Schroeder et al, 2003; Unterwald et al, 1992). However, the ability of DOR, but not MOR, stimulation to inhibit adenylyl cyclase activity is impaired in the NAc following chronic cocaine (Unterwald et al, 1993), and this impairment persists for at least 1 day of cocaine withdrawal (Perrine et al, 2008), coinciding with increased internalization of DOR in NAc neurons (Ambrose-Lanci et al, 2008). Although these changes could modify the ability of MOR and DOR to trigger cocaine relapse in early cocaine withdrawal, we reported that MOR, and not DOR, levels in the NAc core progressively increase from 1 to 6 weeks of withdrawal from chronic cocaine self-administration (Self et al, 2004), and the effect is accompanied by increases in the precursor for $\beta$-endorphin, pro-opiomelanocortin, in the arcuate nucleus of the hypothalamus (Smagula et al, 2005). These findings suggest that progressive increases in MOR signaling in the NAc contribute to time-dependent increases in cocaine-seeking behavior in cocaine withdrawal when animals are exposed to cocaine-paired environments or stressful conditions (Grimm et al, 2001; Sorge and Stewart, 2005; Tran-Nguyen et al, 1998).

Human studies also support a relationship between increased MOR and cocaine craving in abstinence. Thus, MOR binding measured by positron emission tomography is increased in striatal and cortical regions in abstinent cocaine addicts and positively correlates with measures of cocaine craving (Gorelick et al, 2005; Zubieta et al, 1996). In subsequent studies, the upregulation in MOR binding was found to persist for up to 12 weeks of abstinence and positively correlate with the amount of prior cocaine use (Gorelick et al, 2005). Moreover, the upregulation of MOR in abstinence served as an independent predictor of time to relapse in cocaine addicts and positively correlated with the amount of cocaine use during the first month of relapse (Gorelick et al, 2008). Although limitations in detection precluded examination of MOR exclusively in the NAc, our animal data suggest that such long-lasting increases in MOR could functionally increase the propensity for cocaine relapse (Self et al, 2004).

In this regard, treatment with the opioid receptor antagonist naltrexone in combination with behavioral therapy decreased cocaine use over time (Schmitz et al, 2001). When threefold higher doses of naltrexone were utilized in combination with psychosocial treatment, the severity of cocaine use decreased (Pettinati et al, 2008). In response to an acute cocaine dose, addicts reported decreased 'good effects' and 'crash' when treated with naltrexone (Kosten et al, 1992; Sofuoglu et al, 2003), although naltrexone reportedly does not decrease subjective reports of craving elicited by cocaine-associated cues (Modesto-Lowe et al, 1997). Our findings suggest that blockade of MOR and DOR in the NAc contributes to the therapeutic potential of naltrexone in the treatment of cocaine addiction.

\section{ACKNOWLEDGEMENTS}

This study is supported by NIH grants DA 10460, DA 18743, DA 08227, and DA 19274 (D Simmons), and by the Wesley Gilliland Professorship in Biomedical Research (UTSW). We thank Chul Ahn, PhD, and Song Zhang, $\mathrm{PhD}$, in the Department of Biostatistics and Bioinformatics at UT Southwestern Medical Center for their statistical support. We also thank Erin Larson, PhD, Nicole Buzin, Paul Nederhoed, and Joey Webb for their help with animal support.

\section{CONFLICT OF INTEREST}

The authors declare that over the past 3 years, D Self has received compensation from Teva Pharmaceutical Industries, and D Simmons has received no financial support from any individual or corporate entity. There are no personal financial holdings that could be perceived as constituting a potential conflict of interest.

\section{REFERENCES}

Ambrose-Lanci LM, Peiris NB, Unterwald EM, Van Bockstaele EJ (2008). Cocaine withdrawal-induced trafficking of delta-opioid receptors in rat nucleus accumbens. Brain Res 1210: 92-102.

Anderson SM, Bari AA, Pierce RC (2003). Administration of the D1-like dopamine receptor antagonist SCH-23390 into the medial nucleus accumbens shell attenuates cocaine priminginduced reinstatement of drug-seeking behavior in rats. Psychopharmacology 168: 132-138.

Arroyo M, Baker WA, Everitt BJ (2000). Cocaine self-administration in rats differentially alters mRNA levels of the monoamine transporters and striatal neuropeptides. Mol Brain Res 83: 107-120.

Bachtell RK, Whisler K, Karanian D, Self DW (2005). Effects of intra-nucleus accumbens shell administration of dopamine agonists and antagonists on cocaine-taking and cocaine-seeking behaviors in the rat. Psychopharmacology 183: 41-53.

Bakshi VP, Kelley AE (1993). Feeding induced by opioid stimulation of the ventral striatum: role of opiate receptor subtypes. J Pharmacol Exp Ther 265: 1253-1260.

Bonner G, Meng F, Akil H (2000). Selectivity of mu-opioid receptor determined by interfacial residues near third extracellular loop. Eur J Pharmacol 403: 37-44.

Boutrel B (2008). A neuropeptide-centric view of psychostimulant addiction. Br J Pharmacol 154: 343-357.

Burattini C, Burbassi S, Aicardi G, Cervo L (2008). Effects of naltrexone on cocaine- and sucrose-seeking behaviour in response to associated stimuli in rats. Int J Neuropsychopharmacol 11: 103-109.

Churchill L, Kalivas PW (1992). Dopamine depletion produces augmented behavioral responses to a mu-, but not a delta-opioid receptor agonist in the nucleus accumbens: lack of a role for receptor upregulation. Synapse 11: 47-57.

Clayson J, Jales A, Tyacke RJ, Hudson AL, Nutt DJ, Lewis JW et al (2001). Selective delta-opioid receptor ligands: potential PET ligands based on naltrindole. Bioorg Med Chem Lett 11: 939-943.

Comer SD, Lac ST, Curtis LK, Carroll ME (1993). Effects of buprenorphine and naltrexone on reinstatement of cocainereinforced responding in rats. J Pharmacol Exp Ther 267: 1470-1477.

Cornish JL, Kalivas PW (2000). Glutamate transmission in the nucleus accumbens mediates relapse in cocaine addiction. J Neurosci 20: RC89. 
Cunningham ST, Kelley AE (1992). Opiate infusion into nucleus accumbens: contrasting effects on motor activity and responding for conditioned reward. Brain Res 588: 104-114.

Dackis CA, O'Brien CP (2001). Cocaine dependence: a disease of the brain's reward centers. J Subst Abuse Treat 21: 111-117.

de Vries TJ, Babovic-Vuksanovic D, Elmer G, Shippenberg TS (1995). Lack of involvement of delta-opioid receptors in mediating the rewarding effects of cocaine. Psychopharmacology 120: $442-448$.

Doron R, Fridman L, Yadid G (2006). Dopamine-2 receptors in the arcuate nucleus modulate cocaine-seeking behavior. NeuroReport 17: 1633-1636.

Edwards S, Whisler KN, Fuller DC, Orsulak PJ, Self DW (2007). Addiction-related alterations in D1 and D2 dopamine receptor behavioral responses following chronic cocaine self-administration. Neuropsychopharmacology 32: 354-366.

Ford CP, Mark GP, Williams JT (2006). Properties and opioid inhibition of mesolimbic dopamine neurons vary according to target location. J Neurosci 26: 2788-2797.

Furuta T, Zhou L, Kaneko T (2002). Preprodynorphin-, preproenkephalin-, preprotachykinin A- and preprotachykinin B-immunoreactive neurons in the accumbens nucleus and olfactory tubercle: double-immunofluorescence analysis. Neuroscience 114: $611-627$.

Gerrits MA, Kuzmin AV, van Ree JM (2005). Reinstatement of cocaine-seeking behavior in rats is attenuated following repeated treatment with the opioid receptor antagonist naltrexone. Eur Neuropsychopharmacol 15: 297-303.

Gerrits MA, Wiegant VM, Van Ree JM (1999). Endogenous opioids implicated in the dynamics of experimental drug addiction: an in vivo autoradiographic analysis. Neuroscience 89: 1219-1227.

Gorelick DA, Kim YK, Bencherif B, Boyd SJ, Nelson R, Copersino $\mathrm{M}$ et al (2005). Imaging brain mu-opioid receptors in abstinent cocaine users: time course and relation to cocaine craving. Biol Psychiatry 57: 1573-1582.

Gorelick DA, Kim YK, Bencherif B, Boyd SJ, Nelson R, Copersino ML et al (2008). Brain mu-opioid receptor binding: relationship to relapse to cocaine use after monitored abstinence. Psychopharmacology 200: 475-486.

Gracy KN, Svingos AL, Pickel VM (1997). Dual ultrastructural localization of mu-opioid receptors and NMDA-type glutamate receptors in the shell of the rat nucleus accumbens. J Neurosci 17: 4839-4848.

Grimm JW, Hope BT, Wise RA, Shaham Y (2001). Neuroadaptation. Incubation of cocaine craving after withdrawal. Nature 412: 141-142.

Hurd YL, Herkenham M (1992). Influence of a single injection of cocaine, amphetamine or GBR 12909 on mRNA expression of striatal neuropeptides. Mol Brain Res 16: 97-104.

Johnson SW, North RA (1992). Two types of neurone in the rat ventral tegmental area and their synaptic inputs. J Physiol 450: 455-468.

Kalivas PW, Bronson M (1985). Mesolimbic dopamine lesions produce an augmented behavioral response to enkephalin. Neuropharmacology 24: 931-936.

Kalivas PW, Volkow ND (2005). The neural basis of addiction: a pathology of motivation and choice. Am J Psychiatry 162: 1403-1413.

Kelley AE, Baldo BA, Pratt WE, Will MJ (2005). Corticostriatalhypothalamic circuitry and food motivation: integration of energy, action and reward. Physiol Behav 86: 773-795.

Koob GF, Le Moal M (2001). Drug addiction, dysregulation of reward, and allostasis. Neuropsychopharmacology 24: 97-129.

Kosten T, Silverman DG, Fleming J, Kosten TA, Gawin FH, Compton $\mathrm{M}$ et al (1992). Intravenous cocaine challenges during naltrexone maintenance: a preliminary study. Biol Psychiatry 32: 543-548.
Kreek MJ (2001). Drug addictions. Molecular and cellular endpoints. Ann N Y Acad Sci 937: 27-49.

Leone P, Pocock D, Wise RA (1991). Morphine-dopamine interaction: ventral tegmental morphine increases nucleus accumbens dopamine release. Pharmacol Biochem Behav 39: 469-472.

Mansour A, Fox CA, Burke S, Akil H, Watson SJ (1995). Immunohistochemical localization of the cloned mu opioid receptor in the rat CNS. $J$ Chem Neuroanat 8: 283-305.

Mansour A, Khachaturian H, Lewis ME, Akil H, Watson SJ (1987). Autoradiographic differentiation of $\mathrm{mu}$, delta, and kappa opioid receptors in the rat forebrain and midbrain. J Neurosci 7: 2445-2464.

Mantsch JR, Yuferov V, Mathieu-Kia AM, Ho A, Kreek MJ (2004). Effects of extended access to high $v s$ low cocaine doses on selfadministration, cocaine-induced reinstatement and brain mRNA levels in rats. Psychopharmacology 175: 26-36.

Martin TJ, Kim SA, Cannon DG, Sizemore GM, Bian D, Porreca F et al (2000). Antagonism of delta(2)-opioid receptors by naltrindole- $5^{\prime}$-isothiocyanate attenuates heroin self-administration but not antinociception in rats. J Pharmacol Exp Ther 294: 975-982.

McFarland K, Lapish CC, Kalivas PW (2003). Prefrontal glutamate release into the core of the nucleus accumbens mediates cocaineinduced reinstatement of drug-seeking behavior. J Neurosci 23: 3531-3537.

Meyer ME, McLaurin BI, Allen M (1994). Biphasic effects of intraaccumbens mu-opioid peptide agonist DAMGO on locomotor activities. Pharmacol Biochem Behav 47: 827-831.

Modesto-Lowe V, Burleson JA, Hersh D, Bauer LO, Kranzler HR (1997). Effects of naltrexone on cue-elicited craving for alcohol and cocaine. Drug Alcohol Depend 49: 9-16.

Olive MF, Koenig HN, Nannini MA, Hodge CW (2001). Stimulation of endorphin neurotransmission in the nucleus accumbens by ethanol, cocaine, and amphetamine. J Neurosci 21: RC184.

Paxinos G, Watson C (1998). The Rat Brain Stereotaxic Coordinates, 4th edn. Academic Press: New York.

Pelton JT, Kazmierski W, Gulya K, Yamamura HI, Hruby VJ (1986). Design and synthesis of conformationally constrained somatostatin analogues with high potency and specificity for $\mathrm{mu}$ opioid receptors. J Med Chem 29: 2370-2375.

Perrine SA, Sheikh IS, Nwaneshiudu CA, Schroeder JA, Unterwald EM (2008). Withdrawal from chronic administration of cocaine decreases delta opioid receptor signaling and increases anxietyand depression-like behaviors in the rat. Neuropharmacology 54 355-364.

Pettinati HM, Kampman KM, Lynch KG, Suh JJ, Dackis CA, Oslin DW et al (2008). Gender differences with high-dose naltrexone in patients with co-occurring cocaine and alcohol dependence. J Subst Abuse Treat 34: 378-390.

Phillips AG, LePiane FG, Fibiger HC (1983). Dopaminergic mediation of reward produced by direct injection of enkephalin into the ventral tegmental area of the rat. Life Sci 33: 2505-2511.

Phillips PE, Stuber GD, Heien ML, Wightman RM, Carelli RM (2003). Subsecond dopamine release promotes cocaine seeking. Nature 422: 614-618.

Portoghese PS, Sultana M, Takemori AE (1988). Naltrindole, a highly selective and potent non-peptide delta opioid receptor antagonist. Eur J Pharmacol 146: 185-186.

Portoghese PS, Sultana M, Takemori AE (1990). Naltrindole 5 -isothiocyanate: a nonequilibrium, highly selective delta opioid receptor antagonist. J Med Chem 33: 1547-1548.

Pruessner JC, Champagne F, Meaney MJ, Dagher A (2004). Dopamine release in response to a psychological stress in humans and its relationship to early life maternal care: a positron emission tomography study using $\left[{ }^{11} \mathrm{C}\right]$ raclopride. J Neurosci 24: 2825-2831. 
Reid LD, Glick SD, Menkens KA, French ED, Bilsky EJ, Porreca F (1995). Cocaine self-administration and naltrindole, a deltaselective opioid antagonist. NeuroReport 6: 1409-1412.

Roth-Deri I, Schindler CJ, Yadid G (2004). A critical role for beta-endorphin in cocaine-seeking behavior. NeuroReport 15: 519-521.

Roth-Deri I, Zangen A, Aleli M, Goelman RG, Pelled G, Nakash R et al (2003). Effect of experimenter-delivered and self-administered cocaine on extracellular beta-endorphin levels in the nucleus accumbens. J Neurochem 84: 930-938.

Schmidt HD, Anderson SM, Pierce RC (2006). Stimulation of D1like or D2 dopamine receptors in the shell, but not the core, of the nucleus accumbens reinstates cocaine-seeking behaviour in the rat. Eur J Neurosci 23: 219-228.

Schmitz JM, Stotts AL, Rhoades HM, Grabowski J (2001). Naltrexone and relapse prevention treatment for cocainedependent patients. Addict Behav 26: 167-180.

Schroeder JA, Niculescu M, Unterwald EM (2003). Cocaine alters mu but not delta or kappa opioid receptor-stimulated in situ $\left[{ }^{35} \mathrm{~S}\right]$ GTPgammaS binding in rat brain. Synapse 47: 26-32.

See RE, Elliott JC, Feltenstein MW (2007). The role of dorsal vs ventral striatal pathways in cocaine-seeking behavior after prolonged abstinence in rats. Psychopharmacology 194: 321-331.

Self DW, Choi KH, Simmons D, Walker JR, Smagula CS (2004). Extinction training regulates neuroadaptive responses to withdrawal from chronic cocaine self-administration. Learn Mem 11: 648-657.

Self DW, Nestler EJ (1998). Relapse to drug seeking: neural and molecular mechanisms. Drug Alcohol Depend 51: 49-60.

Shalev U, Grimm JW, Shaham Y (2002). Neurobiology of relapse to heroin and cocaine seeking: a review. Pharmacol Rev 54: $1-42$.

Smagula CS, Simmons D, Monteggia L, Self DW (2005). Increased expression of MOR1 mRNA in the anterior nucleus accumbens and POMC mRNA in the anterior arcuate nucleus following long-term withdrawal from cocaine self-administration. Soc Neurosci Abstr 31: 682.14.

Soderman AR, Unterwald EM (2008). Cocaine reward and hyperactivity in the rat: sites of mu opioid receptor modulation. Neuroscience 154: 1506-1516.

Sofuoglu M, Singha A, Kosten TR, McCance-Katz FE, Petrakis I, Oliveto A (2003). Effects of naltrexone and isradipine, alone or in combination, on cocaine responses in humans. Pharmacol Biochem Behav 75: 801-808.

Sorge RE, Stewart J (2005). The contribution of drug history and time since termination of drug taking to footshock stress-induced cocaine seeking in rats. Psychopharmacology 183: $210-217$.

Spealman RD, Barrett-Larimore RL, Rowlett JK, Platt DM, Khroyan TV (1999). Pharmacological and environmental determinants of relapse to cocaine-seeking behavior. Pharmacol Biochem Behav 64: $327-336$

Stewart J (1984). Reinstatement of heroin and cocaine selfadministration behavior in the rat by intracerebral application of morphine in the ventral tegmental area. Pharmacol Biochem Behav 20: 917-923.

Stewart J (2000). Pathways to relapse: the neurobiology of drugand stress-induced relapse to drug-taking. J Psychiatry Neurosci 25: $125-136$
Stewart J, Vezina P (1988). A comparison of the effects of intraaccumbens injections of amphetamine and morphine on reinstatement of heroin intravenous self-administration behavior. Brain Res 457: 287-294.

Stinus L, Nadaud D, Jauregui J, Kelley AE (1986). Chronic treatment with five different neuroleptics elicits behavioral supersensitivity to opiate infusion into the nucleus accumbens. Biol Psychiatry 21: 34-48.

Svingos AL, Clarke CL, Pickel VM (1999). Localization of the deltaopioid receptor and dopamine transporter in the nucleus accumbens shell: implications for opiate and psychostimulant cross-sensitization. Synapse 34: 1-10.

Svingos AL, Moriwaki A, Wang JB, Uhl GR, Pickel VM (1997). MuOpioid receptors are localized to extrasynaptic plasma membranes of GABAergic neurons and their targets in the rat nucleus accumbens. J Neurosci 17: 2585-2594.

Sweep CG, Wiegant VM, De Vry J, Van Ree JM (1989). Betaendorphin in brain limbic structures as neurochemical correlate of psychic dependence on drugs. Life Sci 44: 1133-1140.

Tang XC, McFarland K, Cagle S, Kalivas PW (2005). Cocaineinduced reinstatement requires endogenous stimulation of mu-opioid receptors in the ventral pallidum. J Neurosci 25: 4512-4520.

Tran-Nguyen LT, Fuchs RA, Coffey GP, Baker DA, O’Dell LE, Neisewander JL (1998). Time-dependent changes in cocaineseeking behavior and extracellular dopamine levels in the amygdala during cocaine withdrawal. Neuropsychopharmacology 19: $48-59$.

Unterwald EM, Cox BM, Kreek MJ, Cote TE, Izenwasser S (1993). Chronic repeated cocaine administration alters basal and opioidregulated adenylyl cyclase activity. Synapse 15: 33-38.

Unterwald EM, Horne-King J, Kreek MJ (1992). Chronic cocaine alters brain mu opioid receptors. Brain Res 584: 314-318.

Van der Kooy D, Mucha RF, O'Shaughnessy M, Bucenieks P (1982). Reinforcing effects of brain microinjections of morphine revealed by conditioned place preference. Brain Res 243: 107-117.

Wang H, Pickel VM (1998). Dendritic spines containing mu-opioid receptors in rat striatal patches receive asymmetric synapses from prefrontal corticostriatal afferents. J Comp Neurol 396: 223-237.

Ward SJ, Roberts DC (2007). Microinjection of the delta-opioid receptor selective antagonist naltrindole $5^{\prime}$-isothiocyanate site specifically affects cocaine self-administration in rats responding under a progressive ratio schedule of reinforcement. Behav Brain Res 182: 140-144.

Zangen A, Shalev U (2003). Nucleus accumbens beta-endorphin levels are not elevated by brain stimulation reward but do increase with extinction. Eur J Neurosci 17: 1067-1072.

Zhang M, Balmadrid C, Kelley AE (2003). Nucleus accumbens opioid, GABaergic, and dopaminergic modulation of palatable food motivation: contrasting effects revealed by a progressive ratio study in the rat. Behav Neurosci 117: 202-211.

Zhang M, Kelley AE (1997). Opiate agonists microinjected into the nucleus accumbens enhance sucrose drinking in rats. Psychopharmacology 132: 350-360.

Zubieta JK, Gorelick DA, Stauffer R, Ravert HT, Dannals RF, Frost JJ (1996). Increased mu opioid receptor binding detected by PET in cocaine-dependent men is associated with cocaine craving. Nat Med 2: 1225-1229. 